\title{
Model of Family Life Education based on Family Sustainability
}

\author{
T.Abas, Y.Jubaedah, N.R. Rinekasari \\ Family Welfare Education Study Program \\ Universitas Pendidikan Indonesia \\ tati_abas@yahoo.com
}

\begin{abstract}
This research aimed to develop of family life education model based on the family sustainability. the reasearch was used research and development as a problemsolving approach through stages: 1. the preliminary study, 2. the developing model, and 3. the validation model. The preliminary study conducted activities: (a) literature study pertaining to the matter of research, (b) identifying characteristics of family life education based on the experts opinion, (c) designing model of family life education based the family sustainability. That stage of development model performed: (a) developing teaching materials, (b) testing design model, (c) evaluation and improvements model. Validation model stages performed: (a) test validation model through expert judgement, (b) test validation model empirically, (c) evaluation and improvements model to produce the final model. Finnaly, the result of this study can provide: 1) the model of family life education based on family's sustainability, 2) the teaching materials of family life education based on family sustainability
\end{abstract}

Keywords - Family life education model, family sustainability

\section{INTRODUCTION}

Since 2007, The Family Welfare Education or Pendidikan Kesejahteraan Keluarga, called as PKK Study Program was authorized to operation, tried to passed a best quality of the education scholar. They are expected to contribute academically and professionally in improving the quality of human resources. PKK Study Program have a responsibility to fullfill the society demands in labor field. The society need a professional labor that had a creativity and also proactive in the development of experts qualified field.

Thus, it developed graduates profile as follows: (1) capable to develop and managing the education instructional program of family welfare eduction in accordance with pedagogy's principles in Vocational High School (or SMK) fields of expertise such as social work, cratmanship, and tourism; (2) capable to solve the problems based on the analysis and small research of family welfare education implemented independently or group; (3) capable of performing devotion and counseling in family welfare education for the community; (4) capable of publish scientific work in family welfare education; (5) capable of establish cooperation with various professions in developing the ability of academic and professional the family welfare expertise.
Qualification that developed as PKK Study program's profile graduates referring to UPI development curriculum for a course of education studies, blends the mastery and development educational fields, and others knowledge. They shoud mastery the skills associated with a real situation in the process of educate and learning activities at school. With this model, the education program organized by integrating knowledge (mastery of the theory and reality), practices skill (use methods, an instrument, and a material) and thinking skills (to be logical, critical, creative, reflective, and intuitive); also attitude and personality based on good noble and the values of the local wisdom. This can be developed in the learning process and integrated with the knowledge, skill, attitude and behavior that obtained and shaped by field practice experience (UPI, 2012: 14).

Due to this demand, PKK Study Program curriculum developed the family life education as one of a group field of expertises. Family life education focuses on healthy family functioning within a family systems perspective and provides a primarily preventive approach. The goal of family life education is to teach and foster this knowledge and these skills to enable individuals and families to function optimally (NCFR, 2015).

PKK Study Program was developed the same goal with the NFCR. However, a family life education courses had a lack of good learning experiences in the implementation of core and elective curriculum. Thus, a model family life educational based on family's suistainabilty needed to design. It should be capable to cover comprehensively of the students academic, vocational, and generic skills based on national standard curriculum. Also, the abilities must refer to the work industry, because student or graduates should have a recognition of mastering competencies from the stakeholder.

Prince Edward Island of Home Economics Curriculum (1995) noted that family life education is a program designed to enhance family life by contributing to the development of the student's intellectual, social, emotional, physical, psychological, moral and spiritual capacities in a manner that encourages self image and respect for others

Achdiani, dkk., (2010: 54) found that on her research of problems based learning :

Exercise or training as an understanding and application stage in the lecture is an effective learning component in enhancing students reflective ability in show, analyze and 
solve the problems faced by clients as a result learn from PKK counseling lectures.

From this phenomenon, this research aimed to have the development model of family life educational based on family suistainability.

\section{METHODS}

This research was using a research and development approach. It was implemented in three stages, namely: (1) prelimary study, (2) developing model, and (3) testing model (validation of model).

Research was conducted on the learning implementation of family counseling lectures as expertise lecture of PKK Study Program at Universitas Pendidikan Indonesia. The subjects were learners and dozen of family counseling lectures. Data collection and analysis was conducted in three stages : 1) prelimary study, 2) development model, 3) testing model or validation model.

\section{A. Prelimary study}

We selected an interview, observation, study documentation technique, also, supported by literature review, for producing a design of family life education model based on family's sustainability. The discovery of family life educational model based on family's sustainability that implemented on PKK Study Program curriculum refers to KKNI was described in the form of narrative data, then analyzed qualitatively.

\section{B. Development model}

On this stage, family life eduacation model were judgment by the expert that oriented family's sustainability, then produced the model prepared to be validation The implementation and the result of developing design family life education model based on family's sustainability were described in the form of narrative data, then analyzed qualitatively.

\section{Testing model or validation model}

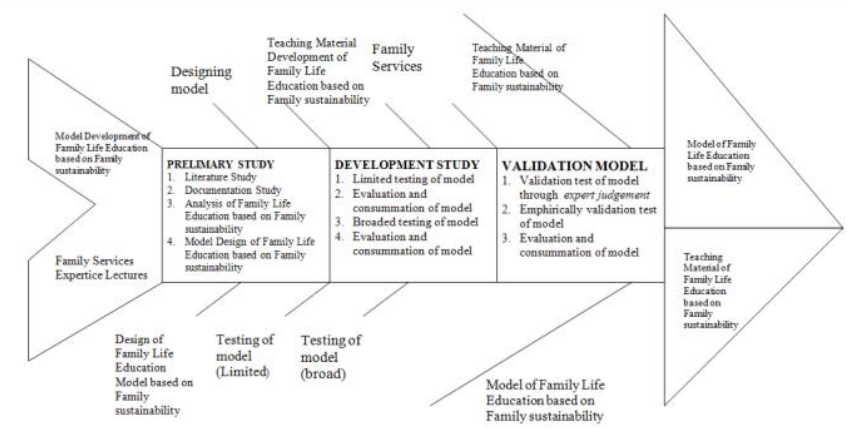

Fig. 1. Research procedures

At validation stage, the model was examined by expert and empirical test to produce family life education model based on family sustainability. Result of validation test was analyzed qualitatively as a conclusions of feasibility model that implemented within scientific and expertise lectures at PKK Study Program.The study was conducted according to the stage of research and development, see fig.1.

\section{RESULTS AND DISCUSSION}

\section{A. Family Counseling Lectures in Curriculum Structure of PKK Study Program at Universitas Pendidikan Indonesia}

The development of science and technology was widely spread so fast must be responded by developing the curriculum at universities that appropriate with society development, the business world and industry, and stakeholder demands. Therefore, PKK Study Program at Universitas Pendidikan Indonesia or UPI was develop it curriculum in accordance with that situation.

Curriculum development of PKK Study Program refers on the platform of the development curriculum of Technological and Vocational Education Faculty (FPTK) and Indonesia of national qualification framework or KKNI. KKNI is qualifications framework competence leveling that could reconcile, equalizes, and integrate the education with the job training, also work experiences in order to giving the competence recognition in accordance with the work structure in various sectors. KKNI was the embodiment of quality and identity of Indonesia nation related to the education system and national training that owned by Indonesia (Santoso, 2011).

The contents description of a family counseling lectures : the concept of PKK counseling, the purpose of PKK counseling, the characteristics and role of PKK counseling, the scope PKK counseling, PKK counseling as social services in the process of change and development values of life, especially in the field of PKK, the guidance principles and counseling that can be applied in PKK counseling, individual, family problems and society problems, problems in family life, PKK counseling approaches and steps.

Family counseling lectures implemented in class theoritically. Also, practices family counseling in the community as family services to providing family sustainability achievement, therefore, the welfare and happy family would be possible.

Designing family life education model based on family sustainability

Family life educational model based on family sustainability developed in three dimensional adapted from Suderadjat (2003), first dimension, is the learning goals which oriented to mastery skills and ability of process or method (methodogical objectives). This is a generic skills (general life skill), because shared by all fields, and is a prerequisite skills, because students is required to possess this skills, so it can mastering and having fields and vocational expertise.

The second dimension, is learning goals which oriented to mastery and ownership of the fundamental concept of scientific (content objectives), and ownership essential matter consisting of the key concepts and the main principles (basic principles). In general, scientific concepts have a key of high 
generalization, in order that the concepts can be used in the another discipline (transferable). The third dimension, is the purpose of learning which oriented to mastery the ability to apply the basic concept (scientific or vocational) in the daily life (life skill objectives).

Family life education based family sustainability are closely linked to harmonious family, because the harmonious is one indication the establishment of the powerful family. Harmonious family is form a connection or relation which is comfortable, peaceful, also, each other remind and reflect affection between husband and wife. Harmony in this family can studied from togetherness, communication and lack of conflict dimensions.

In Indonesia, the efforts to strengthen the family sustainability is conducted in a non-formal and informal, yet there are program that titling and periodic conducted to strengthen the family sustainability. Family sustainability efforts was done individually, hereditary from one generation to generation, and the possibility of deviation or experienced a value decline along with the strong influx of globalization (Hastuti, 2014).

This phenomena and assumption become a reference for household future challenges in Indonesia, and specifically for PKK Study Program who developed the study of family welfare in children milestone. This is one of the aspects of family function, because the all the family member have a development task that relating to duty of raising and child care that required to form of hold or strong families (family sustainability).

The results of research conducted by Sunarti (Hastuti, 2014) indicate that family sustainability give a positive influence on baby growth and development as measured by the nutritional status anthropometry and their position in the development of as measured by the BKB questionnaire. Similarly, family sustainability has some positive effects to the growth of pregnant mothers during pregnancy.

Family life education model developed under charge curriculum of PKK Study Program. Family life education learned in comprehensive on some integrated lectures. Family life education study oriented to the achievement of happy and welfare families, so that it will implicated to the family sustainability.

Learner learning experience on the scientific family life education through activity of family counseling that was held in social institutions as institutions couples of PKK Study Program, and society who request a services for improving their family sustainability.

The community categorized need a service or accompaniment is pre-prosperous and groups of poor families. The family needs servants related to family life education services involved ten terms of family life. Services's focus will be released for groups pre prosperous and poor families oriented to increasing economy of family, inter and intra relations between family, also can build harmonious family so that contribute to an increase in family sustainability.
The implementation of family life education model based on family sustainability can be applied by collaboration between PKK studies through the practice of the pitch at government program that is executed by a group dasawisma in the community.

The tasks and function of Dasa Wisma group, as follows:

1. Noted all the activity in a society / households in accordance with the book

2. Noted pregnant women, birth, death, and mother parturition

3. Giving counseling to families about the implementation of the 10 PKK Basic Program

4. Mobilize people as required

5. Report the results to the pkk banjar / dusun. Group

PKK strategy as the effort to reach as many families as possible, implemented through dasawisma group, are the groups consisting of 1020 household that living nearby. The Head of dasawisma group chosen from and by members of the group. The head of the group dasawisma educate in 10 household and having duties to counseling, generate and noted the condition of the families in its group.

PKK members team is volunteers, who did not receive salary, both women and man, that provides some time to PKK, although the target of PKK are families, especially the women household as the central figure to the family. The coordinator of PKK serve as motivator, facilitators, planner, implementing, control and driving the program. Technical assistance to the families and the run in cooperation with the government related agencies. Family welfare indicators basically referring to principal thoughts of contained among the laws no.10 years 1992 , as follows

a) Pre-welfare family are the families who cannot fulfill one or more than 5 their basic needs. As the 1st family welfare, the needs such as for religious teaching, food, housing, clothes, and health

1) Family welfare phase $I$ is the families that had been fulfilling their basic needs in at least 1) implemented worship by each family members, 2) generally family members eat 2 (two) times a day or more, 3) whole family has a different outfit to at home, working or schools and traveling

2) the piece that widest of the floor home are not from the ground

3) when the child is sick or fertile couples want to family planning brought to facilities officer health.

b) Family welfare phase II namely the families that besides has been able to meet the criteria prosperous I, also, must qualified social psychological 6 to 14 i.e.

1) family members carry out of worship regularly .

2) at least, once a week a family provide meat/ fish / eggs as a side dish

3) all members of families earn least one sets of new clothes per year.

4) the entire family in 3 months in good health .

5) at least, one of the family members from 15 years up had a fixed income. 
6) whole family 10-60 year old could read latin

7) all children aged 5 - 15 to years would be enrolled at the moment .

8) if a live 2 or more, of families still fertile couple wearing contraception (except was pregnant).

c) Family welfare phase III

Tthe family qualified 1 to 14 and also could qualified 15 and 21 requirements development family:

1) has an effort to improve religious learning .

2) some of the family income can set aside for family savings to family savings

3) usually eating with least once a day and that occasion used to communicate among members family

4) to participate in public activities the environment of residence

5) any recreation with out of the house least 1 times / six months

6) can obtain news of a newspaper / tv and magazine

7) family members use transportation in accordance with their condition local.

d) Family welfare phase III plus is a households can meet the criteria I to 21 , and can also meet the criteria 22 and 23 development criteria of his family that is:

1) regularly or at a certain time willingly contributed to community social activities in the form of material

2) the family head or family members active as the association of / foundation / institution the community

e) The poor are pre welfare families with economic reasons and KS - i for economic reasons unable to meet one or more indicators which includes:

1) at least once a week family eat meat / fish / eggs.

2) at the end of the year, the entire family have at least one clothes.

3) the floors least 8 square meters broad for each members.

f) Poor families was pre-welfare families with economic reasons and $\mathrm{KS}$ - I for economic reasons unable to meet one or more indicators which includes:

1) generally the entire family meal 2 times a day or more

2) family members having the dress different to home work / schools and traveling

3) the floor widest not from the ground.

The research is obtained the family life education model based family sustainability as follows:

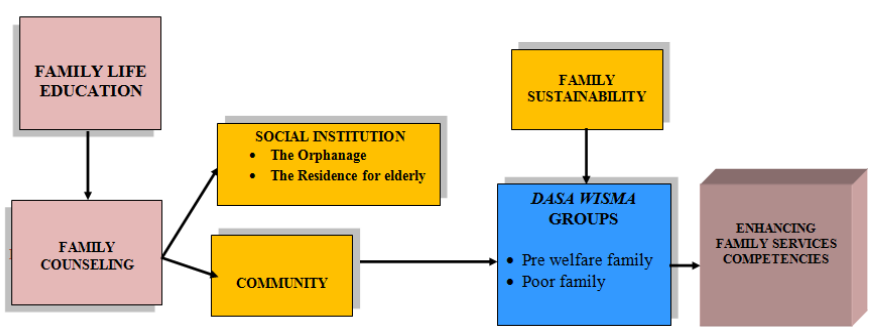

Design of Family Life Education Model based on Family Sustainability

Fig. 2. Design of family eduaction model based on family sustainability

\section{CONCLUSION}

The research activities drawing conclusions can be drawn as follows:

1. Family life education implemented starting in college family counseling as lecture expertise in curriculum structure of PKK Study Program based on KKNI, which includes practices and theory lectures of family services in the community

2. Design of family life education model based family sustainability designed in accordance with the characteristics of the family counseling lectures, and community need for family services in helping to achieve the family sustainability, especially to pre welfare and poor families.

3. Family life educational model based family sustainability should be implemented to provide family services in the community as an effort to help developing family sustainability and achieving welfare and happy family.

\section{ACKNOWLEDGMENT}

Throughout the course of this project, we would llike to thank you to the Director of Higher Education who provided funding and advice through BOPTN Raise.

\section{REFERENCES}

[1] Achdiani, Yani, dkk. (2010). Model Problem Based Learning Dalam Meningkatkan Kemampuan Reflektif Mahasiswa Pada Mata Kuliah Penyuluhan PKK. Bandung: Jurusan PKK FPK UPI.

[2] Hastuti, Dwi (2014). Pengasuhan: Teori dan Prinsip serta Aplikasinya di Indonesia. Bogor: Departemen Ilmu Keluarga dan Konsumen, Fakultas Ekologi Manusia, Institut Pertanian Bogor.

[3] Program Studi PKK. (2012). Profil Program Studi Pendidikan Kesejahteraan Keluarga. Bandung: Program Studi PKK Jurusan PKK FPTK UPI.

[4] Santoso, M. (2011). Kerangka Kualifikasi Nasional Indonesia. Bahan Lokakarya Pengembangan Kurikulum UPI.

[5] Suderadjat, Hari. (2003). Pendidikan Berbasis Luas (BBE) yang Berorientasi Pada Kecakapan Hidup (Life Skill). Bandung: CV. Cipta Cekas Grafika.

[6] NCFR. 2015. What is Family Life Education? https://www.ncfr.org/

[7] Prince Edward Island of Home Economics Curriculum . (1995). Family Life Curriculum. Department on Education and Early Childhood Development. Holman Centre. http://www.gov.pe.ca/photos/original/eecd_fam421A.pdf

[8] UPI. (2012). Rambu-Rambu Pengembangan Kurikulum UPI. Bandung: Universitas Pendidikan Indonesia. 